\title{
Several Fusion Genes Identified in a Spermatic Cord Leiomyoma With Rearrangements of Chromosome Arms 3p and 21q
}

\author{
IOANNIS PANAGOPOULOS ${ }^{1}$, LUDMILA GORUNOVA $^{1}$, KRISTIN ANDERSEN $^{1}$, \\ INGVILD LOBMAIER ${ }^{2}$ and SVERRE HEIM ${ }^{1,3}$ \\ ${ }^{1}$ Section for Cancer Cytogenetics, Institute for Cancer Genetics and Informatics, \\ The Norwegian Radium Hospital, Oslo University Hospital, Oslo, Norway; \\ ${ }^{2}$ Department of Pathology, The Norwegian Radium Hospital, Oslo University Hospital, Oslo, Norway; \\ ${ }^{3}$ Institute of Clinical Medicine, Faculty of Medicine, University of Oslo, Oslo, Norway
}

\begin{abstract}
Background/Aim: Benign smooth-muscle tumors, leiomyomas, occur in nearly every organ but are most common in the uterus. Whereas much is known about the genetics of uterine leiomyomas, little genetic information exists about leiomyomas of other organs. Here, we report and discuss the genetic findings in a para-testicular leiomyoma. Materials and Methods: Cytogenetic, array comparative genomic hybridization (aCGH) RNA sequencing, reverse-transcription polymerase chain reaction (RT-PCR), and Sanger sequencing analyses were performed on a leiomyoma of the spermatic cord removed from a 61 year-old man. Results: The karyotype was 48 50,XY,add(3) $(p 21),+4,+7,+8,+9$, add $(21)(q 22)[c p 9] / 46, X Y[2] . \quad a C G H$ confirmed the trisomies and also detected multiple gains and losses from $3 p$ and $21 q$. RNA sequencing detected the chimeras ARHGEF3-CACNA2D2, TRAK1-TIMP4, ITPR1DT-NR2C2, CLASP2-IL17RD, ZNF621-LARS2, CNTN4RHOA, and NR2C2-CFAP410. All chimeras were confirmed by RT-PCR and Sanger sequencing. Conclusion: Our data, together with those previously published, indicate that a group of leiomyomas may be cytogenetically characterized by aberrations of $3 p$ and the formation of fusion genes.
\end{abstract}

This article is freely accessible online.

Correspondence to: Ioannis Panagopoulos, Section for Cancer Cytogenetics, Institute for Cancer Genetics and Informatics, The Norwegian Radium Hospital, Oslo University Hospital, Montebello, PO Box 4954 Nydalen, NO-0424 Oslo, Norway. Tel: +47 22782362, e-mail: ioannis.panagopoulos@rr-research.no

Key Words: Spermatic cord leiomyoma, para-testicular leiomyoma, cytogenetics, chromosome arm $3 \mathrm{p}$, fusion genes.
Leiomyomas are benign smooth-muscle tumors. They have been described in nearly every organ but are most common in the uterus (fibroids) (1-5).

Much is known about the genetics, and hence the pathogenesis, of uterine leiomyomas (6-9). In brief, most uterine leiomyomas are cytogenetically characterized by the presence of one or more of the following cytogenetic aberrations: $\mathrm{t}(12 ; 14)(\mathrm{q} 15 ; \mathrm{q} 23-24) ; \quad \operatorname{del}(7)(\mathrm{q} 21.2 \mathrm{q} 31.2)$; rearrangements involving $6 \mathrm{p} 21,10 \mathrm{q} 22$, and $1 \mathrm{p}$; trisomy 12 ; deletions of $3 \mathrm{q}$; and changes of the $\mathrm{X}$ chromosome $(10,11)$. These chromosomal aberrations rearrange and deregulate the following genes: High mobility group AT-hook 2 (HMGA2) on $12 \mathrm{q} 14$, RAD51 paralog $\mathrm{B}$ (RAD51B) on 14q24, cut-like homeobox $1(C U X 1)$ on $7 \mathrm{q} 22$, procollagen C-endopeptidase enhancer (PCOLCE) on 7q22, HMGA1 (on $6 \mathrm{p} 21)$, lysine acetyltransferase $6 \mathrm{~B}(K A T 6 B)$ on $10 \mathrm{q} 22$, and collagen type IV alpha 5 chain/collagen type IV alpha 6 chain (COL4A5/ COL4A6) on Xq22 (6-9). Additionally, point mutations of the mediator complex subunit 12 (MED12) gene (on Xq13) have also been reported to be frequent in uterine leiomyomas (12-15). Very little genetic information exists on leiomyomas of other organs, such as gastrointestinal (16-20) and retroperitoneal leiomyomas (2123). A single para-testicular leiomyoma has also been genetically examined (24).

In the present study, we report rearrangements of the $p$ arm of chromosome 3 in a leiomyoma of the spermatic cord leading to multiple fusion genes. We review the literature and conclude that such $3 p$ aberrations may be characteristic of a leiomyoma subgroup.

\section{Materials and Methods}

Ethics statement. The study was approved by the regional Ethics Committee (Regional komité for medisinsk forskningsetikk Sør- Øst, 
Norge, http://helseforskning.etikkom.no) and written informed consent was obtained from the patient. The Ethics Committee's approval included a review of the consent procedure. All patient information has been de-identified.

Case description. A small lump was detected in the groin of a 60year-old man. Core-needle biopsy showed a leiomyomatous tumor with uncertain malignant potential. The tumor was resected. The tumor consisted of bundles of smooth muscle cells without atypia (Figure 1). There was no mitotic activity nor necrosis. The final diagnosis was spermatic cord leiomyoma.

G-Banding karyotyping and array comparative genomic hybridization ( $a C G H)$. analyses. Fresh tissue from a representative area of the tumor was analyzed cytogenetically as previously described (25). Genomic DNA was extracted from the tumor using the Maxwell RSC Instrument and Maxwell RSC Tissue DNA Kit (Promega, Madison, WI, USA), the concentration was measured using Quantus Fluorometer and the QuantiFluor ONE dsDNA System (Promega), and aCGH was performed using CytoSure array products (Oxford Gene Technology, Begbroke, Oxfordshire, UK) as previously described (26).

RNA sequencing. Total RNA was extracted from frozen tumor tissue adjacent to that used for cytogenetic analysis and histological examination using miRNeasy Mini Kit (Qiagen, Hilden, Germany). One microgram of total RNA from the tumor was sent to the Genomics Core Facility at the Norwegian Radium Hospital, Oslo University Hospital for high-throughput paired-end RNAsequencing. Fusion transcripts were found using FusionCatcher software $(27,28)$.

Reverse transcription PCR (RT-PCR) and Sanger sequencing analyses. The primers used for PCR amplification and Sanger sequencing analyses are shown in Table I. The primer combinations and the corresponding fusion transcripts are presented in Table II. The iScript Advanced cDNA Synthesis Kit for RT-PCR was used to reverse transcribe $1 \mu \mathrm{g}$ of total RNA according to the manufacturer's instructions (Bio-Rad, Hercules, CA, USA). cDNA corresponding to $20 \mathrm{ng}$ total RNA was used as template in subsequent PCR assays. BigDye Direct Cycle Sequencing Kit was used to perform both PCR and cycle (Sanger) sequencing according to the company's recommendations (ThermoFisher Scientific, Waltham, MA, USA). Sequencing was run on an Applied Biosystems SeqStudio Genetic Analyzer system (ThermoFisher Scientific). For computer analysis of sequence data, the basic local alignment search tool (BLAST) software was used (29).

\section{Results}

The G-banding analysis (Figure 2A) yielded the following karyotype:

48 50,XY,add(3)(p21),+4,+7,+8,+9, $, \operatorname{add}(21)(\mathrm{q} 22)[\mathrm{cp} 9] / 46, \mathrm{XY}[2]$.

aCGH confirmed trisomy for chromosomes $4,7,8$, and 9 (Figure 2B). In addition, multiple gains and losses were detected on the p arm of chromosome 3 (Figure 2C) and on the $\mathrm{q}$ arm of chromosome 21 (Figure 2D).
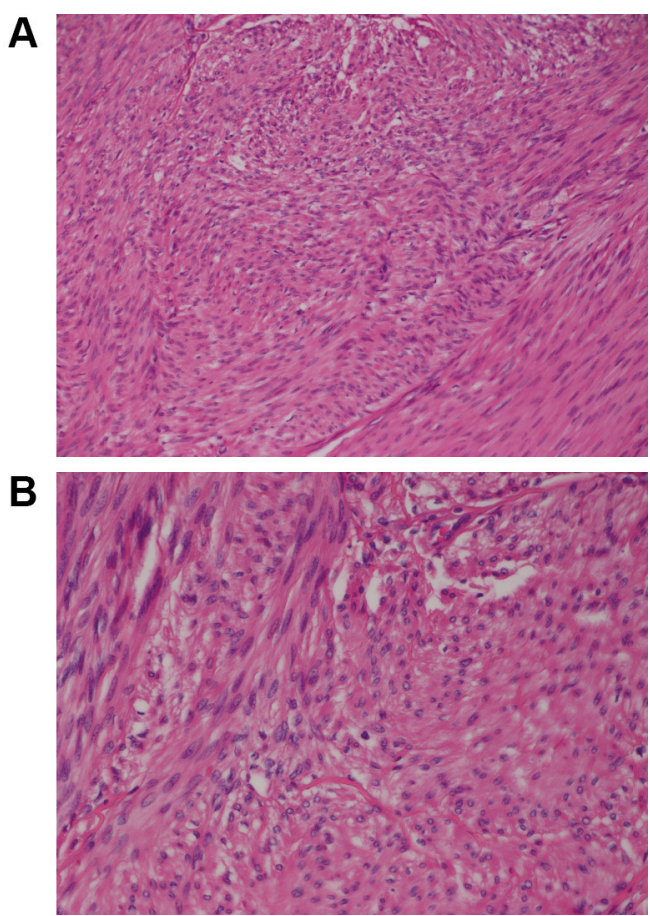

Figure 1. Microscopic examination of the spermatic cord leiomyoma. Hematoxylin and eosin-stained section showing bundles of elongated cells with cigar-shaped nuclei and eosinophilic cytoplasm. Original magnification, A: 20x; B: 40x.

RNA sequencing analysis with FusionCatcher detected seven fusion genes (Table III, Figure 3A). One transcript was detected for each of the chimeras inositol 1,4,5-trisphosphate receptor divergent transcript-nuclear receptor subfamily 2 group C member 2 (ITPRI-DT-NR2C2), cytoplasmic linker associated protein 2-interleukin 17 receptor D (CLASP2ILI7RD), nuclear receptor subfamily 2 group $\mathrm{C}$ member $2-$ cilia and flagella-associated protein 410 (NR2C2-CFAP410), zinc finger protein 621-leucyl-tRNA synthetase 2, mitochondrial (ZNF621-LARS2), and contactin 4-ras homolog family member A (CNTN4-RHOA), whereas two chimeric transcripts were detected for the fusion genes Rho guanine nucleotide exchange factor 3-calcium voltage-gated channel auxiliary subunit alpha2delta 2 (ARHGEF3$C A C N A 2 D 2)$ and trafficking kinesin protein 1-TIMP metallopeptidase inhibitor 4 (TRAK1-TIMP4) (Table III). In six of the fusion genes, both the 5 '-end and 3 '-end fusion partner genes were mapped on chromosome arm $3 p$ (Table III, Figure 3A). In the seventh, the NR2C2-CFAP410 chimera, the 5'-end partner gene, $N R 2 C 2$, was from $3 \mathrm{p} 25.1$, whereas CFAP410 was from 21q22.3 (Tables I and III). All fusion transcripts were verified using RT-PCR and Sanger sequencing analyses (Figure 3B). 


\section{Discussion}

Prior to the present study, to our knowledge, only a single para-testicular leiomyoma, located beneath the tunica albuginea, had been cytogenetically described, by Gorunova et al. (24). That tumor had an abnormal karyotype: $46, X Y, \operatorname{der}(5) \mathrm{t}(5 ; 14)(\mathrm{q} 31 ; \mathrm{q} 24), \operatorname{der}(14) \mathrm{t}(12 ; 14)(\mathrm{q} 15 ; \mathrm{q} 24)$. The net imbalance of the structural rearrangements thus seemed to be the loss of 5q31qter and gain of 12q15qter. Molecular investigations were not performed, but strong nuclear immunostaining was found for the HMGA2 protein in the tumor cells, suggesting that the $\operatorname{der}(14) \mathrm{t}(12 ; 14)(\mathrm{q} 15 ; \mathrm{q} 24)$ dysregulated the expression of the HMGA2 gene. Because $\mathrm{t}(12 ; 14)(\mathrm{q} 15 ; \mathrm{q} 24)$ is the most frequent translocation in uterine leiomyomas and leads to overexpression of $H M G A 2$, the authors concluded that a common pathogenetic pathway exists for both para-testicular (male) and uterine (female) leiomyomas (24).

The present leiomyoma was found in the spermatic cord and had different cytogenetic aberrations from those described by Gorunova et al. (24). Trisomies were found for chromosomes 4, 7,8, and 9, whereas structural aberrations affected chromosome arms $3 p$ and 21q (Figure 2A). The observed numerical aberrations have also been reported in leiomyomas (30): trisomies for chromosomes 4, 8, and 9 in uterine leiomyomas $(16,31-35)$ and trisomy 7 in uterine, bladder, and gastric leiomyomas $(16,17,31,36)$.

Rearrangements of the $3 p$ arm were reported in 22 uterine leiomyomas (30). In 12 of them, the $3 p$ aberration was found together with rearrangements of chromosome bands $12 q 14 \sim 15$ or band 6 p21. Leiomyoma aberrations in the region $12 \mathrm{q} 14 \sim 15$ target the HMGA2 gene, whereas aberrations in 6p21 target HMGAl $(37,38)$. Reports have been published on nine leiomyomas with aberration in the $\mathrm{p}$ arm of chromosome 3 without microscopically visible involvement of 12q14 15 or 6p21 (Table IV) $(31,32,35,39$ 42). Structural rearrangement of the $21 \mathrm{q}$ arm were reported in 12 uterine leiomyomas, always together with aberrations of $6 \mathrm{p}$ (often $6 \mathrm{p} 21$ ) or $12 \mathrm{q} 14 \sim 15(32,38,39,43-46)$.

The aCGH investigation of the tumor in our case not only confirmed trisomies for chromosomes $4,7,8$, and 9 , but also showed multiple gains and losses of material from chromosome arms 3p and 21q (Figure 2B-D), suggesting that the rearrangements detected in $3 p$ and $21 q$, add(3)(p21) and $\operatorname{add}(21)(q 22)$ were more complex than those seen in Gbanded preparations. RNA sequencing detected six fusion genes, ARHGEF3-CACNA2D2, TRAK1-TIMP4, ITPR1DT-NR2C2, CLASP2-IL17RD, ZNF621-LARS2, and CNTN4-RHOA, with both 5'- and 3'-end fusion partner genes located on $3 \mathrm{p}$ (Table III and Figure $3 \mathrm{~A}$ ), and one fusion gene, NR2C2-CFAP410, with the 5'-end partner (NR2C2) from $3 \mathrm{p}$ and the 3 '-end partner gene (CFAP410) from $21 \mathrm{q}$ (Table III). All of them were verified by RT-

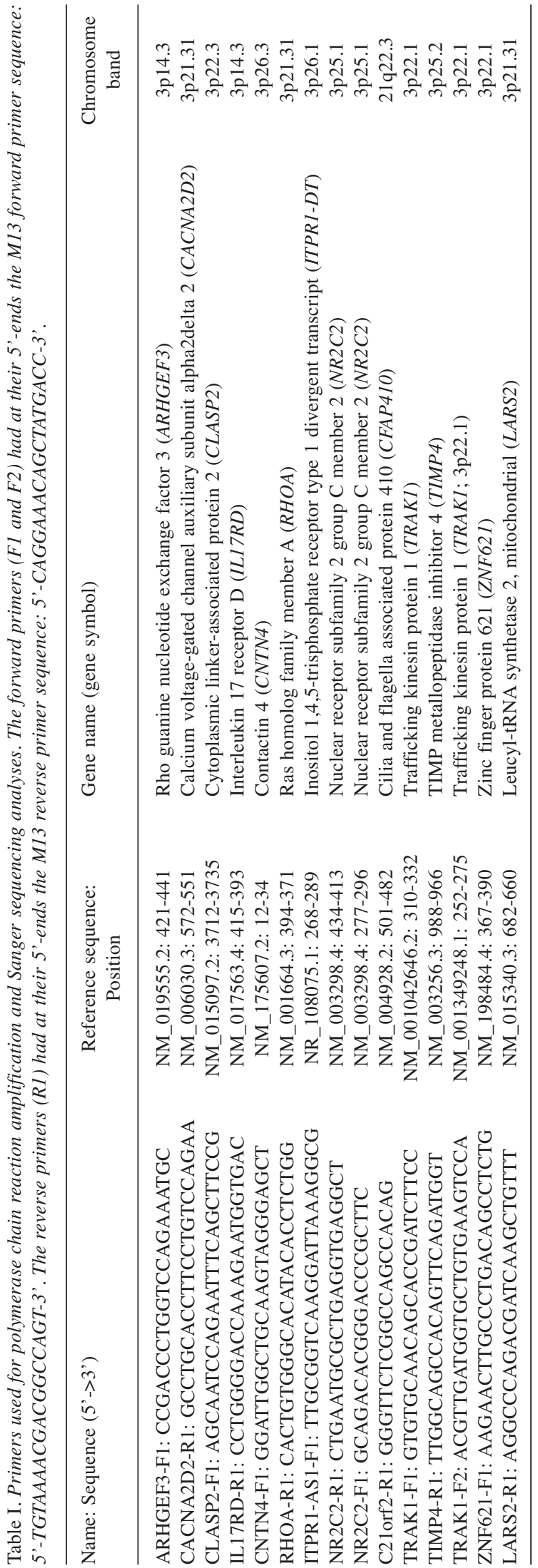


Table II. Primer combinations for polymerase chain reaction amplification to detect fusion transcripts.

\begin{tabular}{lcc}
\hline Primer combination & Fusion transcript $\left(5^{\prime}->3^{\prime}\right)$ & Type of fusion \\
\hline ITPR1-AS1-F1/NR2C2-R1 & ITPR1-DT-NR2C2 & Promoter-replacement-chimera \\
ARHGEF3-F1/CACNA2D2-R1 & ARHGEF3-CACNA2D2 & Out-of-frame \\
CLASP2-F1/IL17RD-R1 & CLASP2-IL17RD & In-frame \\
TRAK1-F1/TIMP4-R1 & TRAK1-TIMP4 & In-frame \\
TRAK1-F2/TIMP4-R1 & TRAK1-TIMP4 & In-frame \\
NR2C2-F1/C21 1 rf2-R1 & NR2C2-CFAP410 \\
ZNF621-F1/LARS2-R1 & ZNF621-LARS2 & Promoter-replacement-chimera \\
CNTN4-F1/RHOA-R1 & CNTN4-RHOA & In-frame \\
\end{tabular}

PCR/Sanger sequencing methodologies (Tables I and II; Figure 3B).

The data indicated that chromothripsis involving chromosome arms $3 p$ and $21 q$ occurred in the tumor, causing the generation of multiple fusion genes $(47,48)$. In this phenomenon, through some unusual, cataclysmic event, a chromosome breaks into many fragments, whereupon these fragments, or some of them, are randomly reassembled (47, 48). Some chromosome fragments are lost through this process while some fusion genes with oncogenic potential are generated at the junctions of the assembled fragments $(47,48)$. Chromothripsis has been detected in uterine leiomyomas which had neither mutations in MED12 or fumarate hydratase genes, nor $12 \mathrm{q} 14 \sim 15$ or $6 \mathrm{p} 21$ chromosomal rearrangements (49-52).

Three types of chimeras were found in our case of paratesticular leiomyoma: The first type, illustrated by the fusions CNTN4-RHOA, ITPRI-DT-NR2C2, and $N R 2 C 2-C F A P 410$, was the promoter-replacement chimera in which 5 '-end untranslated regions of the 5 '-end fusion partner gene replaced the 5'-end untranslated regions of the 3 '-end fusion partner gene. Consequently, the 3'-end fusion partner comes under the control of the 5 '-end fusion partner gene promoter. Thus, in the CNTN4-RHOA transcript, the first untranslated exon of CNTN4, which is highly expressed in testis, replaced the first untranslated exon of $R H O A$, bringing the entire coding part of RHOA under control of the CNTN4 promoter (53). RHOA codes for a member of the Rho family of small GTPases with multiple cellular and biological functions (54-58). Dysregulation of RHOA and other members of the Rho family of small GTPases has been reported in many neoplasias $(59,60)$.

In ITPR1-DT-NR2C2, the first untranslated exon of $I T P R I-D T$, which is part of the ITPRI promoter, replaced the first untranslated exon of $N R 2 C 2(61,62)$. Consequently, the coding part of NR2C2 came under the control of the ITPRI promoter. NR2C2 protein belongs to the nuclear hormone receptor family, acts as a ligand-activated transcription factor and plays a role in many biological processes such as development, cellular differentiation, and homeostasis (63). In the NR2C2-CFAP410 chimeric transcript, the first untranslated exon of NR2C2 fused to exon 4 of CFAP410. In exon 4 of $C F A P 410$, there is an ATG which could act as a starting codon (NM_004928.3; position 521-523; XM_017028472.1; 421-423). In NR2C2-CFAP410, the part of CFAP410 coding for the last 147 amino acids (positions 109-256 in the sequence with accession number NP_0049 19.1; protein with accession number XP_016883961.1) comes under the control of the NR2C2 promoter. Four alternatively spliced transcript variants have been found for the CFAP410 gene. Three of the transcript variants code for mitochondrial proteins. The fourth transcript (accession number NM_001271442.1) codes for a cytoplasmic protein lacking the mitochondrion-target peptide (NP_001258371.1; https://www.ncbi.nlm.nih.gov/gene/755). CFAP410 was found to form a complex with NIMA-related serine/threonine kinase 1 (NEK1) protein and is involved in DNA-damage repair (64). Similarly to the fourth transcript variant of CFAP410, the putative CFAP410 translated from the NR2C2CFAP410 chimera of this tumor would also be expected to lack the mitochondrion-target peptide and might interfere with the CFAP410/NEK1 complex and DNA-damage repair.

The second type of chimera involves out-of-frame transcripts. In the two detected ARHGEF3-CACNA2D2 transcripts, exon 1 or 2 of $A R H G E F 3$ fused with exon 2 of $C A C N A 2 D 2$, introducing a stop codon shortly after the junctions. ARHGEF3 (also known as XPLN) codes for guanine nucleotide exchange factor 3 , which specifically activates Rho GTPase family members RHOA and RHOB $(65,66)$. The putative truncated form of ARHGEF3 would lack the carboxyl terminal part of the ARHGEF3 protein responsible for guanine nucleotide exchange factor activity but retain the amino terminal part of the protein which interacts with mammalian target of rapamycin complex 2 (mTORC2), inhibiting mTORC2 kinase activity $(66,67)$. The presence of the truncated ARGEF3 protein and its possible functions cannot be determined without further cellular studies. Nevertheless, the ARHGEF3-CACNA2D2 


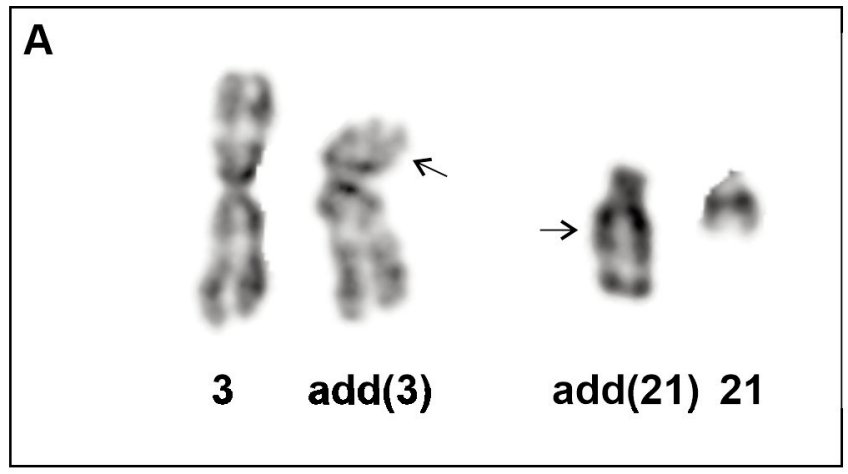

B

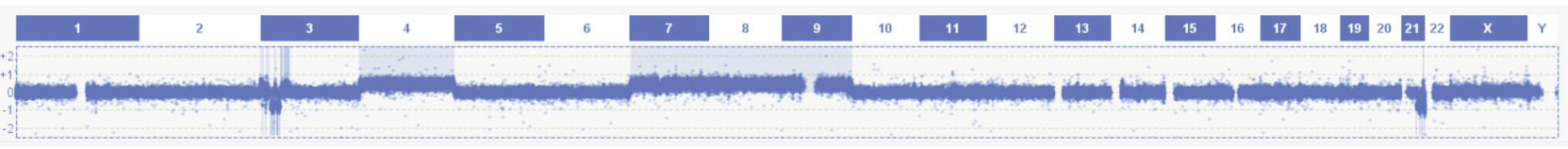

C

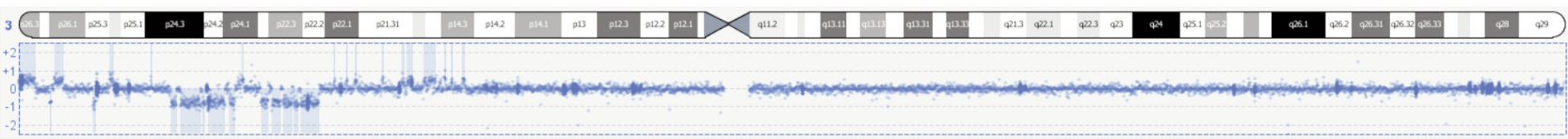

D

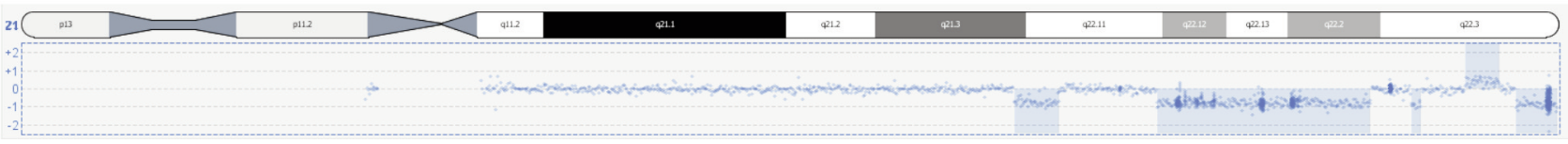

Figure 2. Cytogenetic and array comparative genomic hybridization (aCGH) analyses of the spermatic cord leiomyoma. A: Partial karyotype showing the add(3) and add(21) chromosomes with corresponding normal chromosome homologs. B: aCGH showing gains of one copy of each of chromosomes 4, 7, 8, and 9, as well as multiple gains and losses of genomic material from the p arm of chromosome 3 and $q$ arm of chromosome 21. C: aCGH showing multiple gains and losses of genomic material from the $p$ arm of chromosome 3. D: aCGH showing the multiple gain and losses on the q arm of chromosome 21.

transcript indicated further the dysfunction of RHOA signal transduction in this tumor.

The third type of chimera resulted in in-frame transcripts translated into chimeric proteins. In the ZNF621-LARS2 transcript, exon 2 of ZNF621 fused in-frame to exon 5 of LARS2. In the chimeric ZNF621-LARS2, the first 121 amino acids of LARS 2 are replaced by the first eight amino acids of ZNF621. The LARS2 gene codes for a mitochondrial leucyl-tRNA synthetase with a mitochondrial targeting signal within its first 50 amino acids (68). Thus, since the mitochondrial targeting signal is absent from the chimeric ZNF621-LARS2 protein, the protein would probably be unable to enter the mitochondrion from the cytosol.

The two in-frame TRAK1-TIMP4 fusion transcripts would also give rise to chimeric proteins. The ubiquitously expressed TRAK1 gene codes for trafficking kinesin-binding protein 1 which is involved in mitochondrial and endosometo-lysosome trafficking (69-74). Based on the reference sequence NP_001036111.1, the 953 amino acids-long TRAK1 protein has the following regions: A huntingtinassociated protein 1 conserved region between amino acids $50-353$ binding to huntingtin in a polyglutamine repeatlength-dependent manner; a region between amino acids 359-509 which interacts with hepatocyte growth factorregulated tyrosine kinase substrate protein; a region named milton between 416-583 which recruits the heavy chain of kinesin to mitochondria enabling the motor movement function of kinesin; and a region between amino acids 658672 which interacts with $O$-linked $N$-acetylglucosamine (GlcNAc) transferase protein $(70-72,75,76)$. 
Table III. Fusion transcripts detected in the spermatic cord leiomyoma using RNA sequencing and FusionCatcher.

\begin{tabular}{|c|c|c|c|}
\hline \multicolumn{2}{|c|}{ Fusion partner } & \multicolumn{2}{|l|}{$\begin{array}{l}\text { Cytogenetic location } \\
\text { of partner }\end{array}$} \\
\hline 5'-End & 3'-End & 5'-End/3'-End & Fusion_sequence \\
\hline CNTN4 & RHOA & $3 \mathrm{p} 26.3 / 3 \mathrm{p} 21.31$ & $\begin{array}{l}\text { GCCGCACCCGAGGCTCTCGCCAGCCCGGCGCCCCGGTGCTGAG* } \\
\text { CAATGGCTGCCATCCGGAAGAAACTGGTGATTGTTGGTGATGG }\end{array}$ \\
\hline$I T P R 1-D T$ & $N R 2 C 2$ & $3 \mathrm{p} 26.1 / 3 \mathrm{p} 25.1$ & $\begin{array}{l}\text { AAACCAAGCCTGGGAGCGACGGTCCACGCAAGCGGAGACACAG* } \\
\text { GTAACACGTACACAGACCTCTCGGCCGGAATCTCCAGGGATGA }\end{array}$ \\
\hline$N R 2 C 2$ & CFAP410 & $3 \mathrm{p} 25.1 / 21 \mathrm{q} 22.3$ & $\begin{array}{l}\text { ACACGGGACCCGCTTCGAGGCCGCTTTGGCGCCAAATCCTGAG* } \\
\text { TGTCAACAGCATCTCCACCCTGGAGCCTGTGAGCCGGTGCCAG }\end{array}$ \\
\hline CLASP2 & $I L 17 R D$ & $3 \mathrm{p} 22.3 / 3 \mathrm{p} 14.3$ & $\begin{array}{l}\text { TGAGCCATTGAAAAGGGATTCTAAAAAAGATGATGGCGATTCA* } \\
\text { GGAGTGGGGCCAGCCAGCAGAAACAGTGGGCTGTACAACATCA }\end{array}$ \\
\hline ZNF621 & LARS2 & $3 \mathrm{p} 22.1 / 3 \mathrm{p} 21.31$ & $\begin{array}{l}\text { AAGCCAGGGGACATCCGCCATGCTCCAAACAACTTGGCCTCAG* } \\
\text { GTCATCAACCCCATGGGATGGGATGCTTTTGGATTGCCTGCTG }\end{array}$ \\
\hline TRAK1 & TIMP4 & $3 \mathrm{p} 22.1 / 3 \mathrm{p} 25.2$ & $\begin{array}{l}\text { GACCTCACAACCGAGCAAATTGAAGAGACGTTAAAATACTTCC* } \\
\text { GTCAGGTCCTCAGTGATGGAAAAGTCTTCATCCATCTGTGCAA }\end{array}$ \\
\hline TRAK1 & TIMP4 & $3 \mathrm{p} 22.1 / 3 \mathrm{p} 25.2$ & $\begin{array}{l}\text { GATTATTATGAACTAGACTGGTATTATGAAGAATGCTCGGATG* } \\
\text { GTCAGGTCCTCAGTGATGGAAAAGTCTTCATCCATCTGTGCAA }\end{array}$ \\
\hline ARHGEF3 & CACNA2D2 & $3 \mathrm{p} 14.3 / 3 \mathrm{p} 21.31$ & $\begin{array}{l}\text { CGTCAATCAGATGCTTACATCCAAGGAAATCAAACGTCAGGAG* } \\
\text { GATGCAGCACTGGGCCCGGCGTCTGGAGCAGGAGGTCGACGGC }\end{array}$ \\
\hline$A R H G E F 3$ & CACNA2D2 & $3 \mathrm{p} 14.3 / 3 \mathrm{p} 21.31$ & $\begin{array}{l}\text { CGTGAAGGCCACGCCATTAAAGCGCTTCAGTCAAACCCTGCAG* } \\
\text { GATGCAGCACTGGGCCCGGCGTCTGGAGCAGGAGGTCGACGGC }\end{array}$ \\
\hline
\end{tabular}

Table IV. Reported leiomyomas carrying a cytogenetic aberration in the p arm of chromosome 3.

\begin{tabular}{|c|c|c|}
\hline Case & Reported karyotype & Author (Reference) \\
\hline 1 & $46, X X, \operatorname{inv}(3)(p 12 q 24)$ & Nilbert et al. 1988 (40) \\
\hline 2 & $46, X X, \operatorname{ins}(2 ; 3)(q 31 ; p 12 p 25)$ & Nilbert et al. 1990 (32) \\
\hline 3 & $46, X X, \operatorname{del}(3)(\mathrm{p} 14)$ & Nilbert et al. 1990 (32) \\
\hline 4 & $46, \mathrm{XX}, \mathrm{t}(3 ; 7)(\mathrm{p} 11 ; \mathrm{p} 11)$ & Nilbert et al. 1990 (32) \\
\hline 5 & $46, \mathrm{XX}, \operatorname{del}(3)(\mathrm{p} 13 \mathrm{p} 14)$ & Hu \& Surti 1991 (31) \\
\hline 6 & $46, X X,-2, \operatorname{add}(3)(\mathrm{p} 25-26), \operatorname{del}(5)(\mathrm{q} 11),+\operatorname{mar} / 46, \operatorname{idem},+\operatorname{del}(3)(\mathrm{p} 14),-8$ & Vanni et al. 1991 (42) \\
\hline 7 & $46, \mathrm{XX}, \mathrm{t}(1 ; 3)(\mathrm{p} 13 ; \mathrm{p} 12)$ & Meloni et al. 1992 (35) \\
\hline 8 & $46, X X, \operatorname{der}(3) \operatorname{dic}(3 ; 10)(\mathrm{p} 11 ; \mathrm{q} 25) \operatorname{del}(3)(\mathrm{q} 13), \operatorname{der}(10) \mathrm{t}(3 ; 10)(\mathrm{q} 28 ; \mathrm{q} 25) \operatorname{del}(3)(\mathrm{p} 11 \mathrm{q} 13)$ & Stern et al. 1992 (41) \\
\hline 9 & $46, X X, \operatorname{inv}(3)(\mathrm{p} 21 \mathrm{q} 27)$ & Karaiskos et al. 1995 (39) \\
\hline 10 & $48 \sim 50, X Y, \operatorname{add}(3)(\mathrm{p} 21),+4,+7,+8,+9, \operatorname{add}(21)(\mathrm{q} 22)[\mathrm{cp} 9]$ & Present \\
\hline
\end{tabular}

TIMP4 which codes for tissue inhibitor metalloproteinase 4 , is weakly expressed in testis (77) and inhibits many metalloproteinases (78-80). The inhibitory property of TIMP4 was shown to depend on its $N$-terminal part, between residues 1-127, which contains a site of interaction with the catalytic domain of metalloproteinases $(79,80)$. In the tumor investigated here, the two translated TRAK1-TIMP4 chimeric proteins would lack all the above-mentioned functional regions of TRAK1 and residues 1-127 of TIMP4 which interact with and inhibit metalloproteinases. Their role in tumorigenesis is difficult to assess.

Based on the reference sequences NM_015097.2/ NP_055912.2 for CLASP2 and NM_017563.4/NP_060033.3 for
IL17RD, the CLASP2-IL17RD chimeric transcript would be expected to consist of exons 1 to 34 of CLASP2 and exons 2 to 13 of ILI7RD, be 12317 bp-long, and code for an 1,892 amino acid protein composed of amino acids 1 to 1,195 from CLASP2 and 43 to 739 from IL17RD. The CLASP2 gene codes for cytoplasmic linker protein-associating protein that is a microtubule plus end tracking protein $(81,82)$. CLASP2 is localized to the distal ends of microtubules and is involved in the regulation of microtubule dynamics (83). Microtubules switch between phases of growth and shrinkage through transitions known as microtubule catastrophe and rescue (84). CLASP2 was found to specifically suppress microtubule catastrophe and promote rescue without affecting the rates of 
A

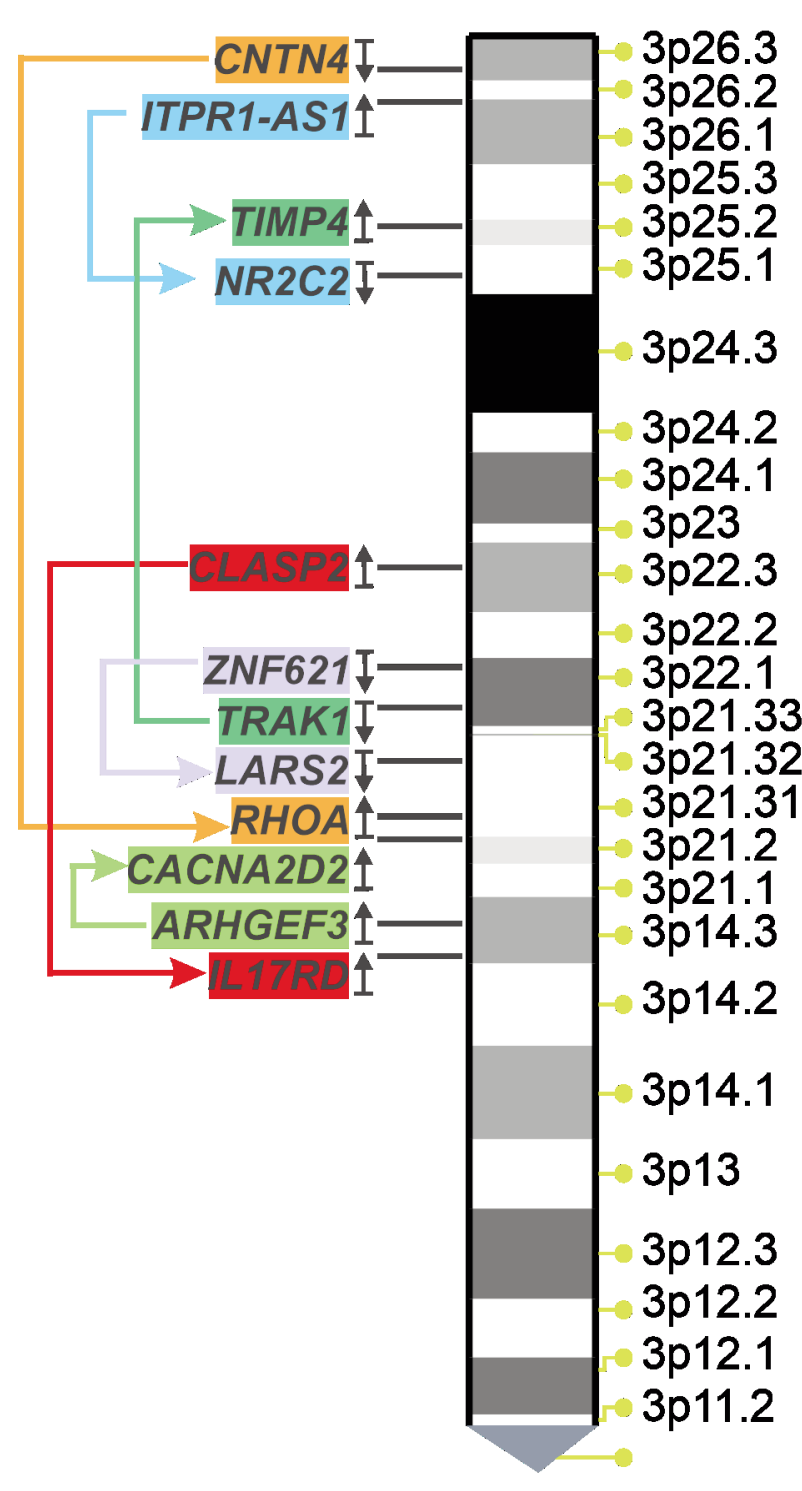

B

CNTN4 exon 1 : RHOA exon 2

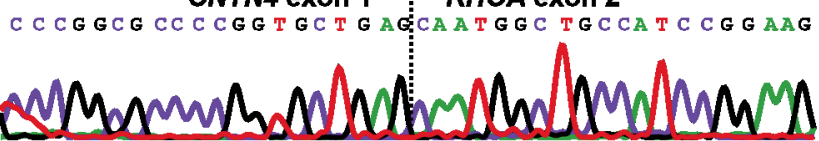

ITPR1-DT exon $1:$ NR2C2 exon 2

C C ACG C A A C G G AG ACAC AGGTAACACGTACACAGACCTC

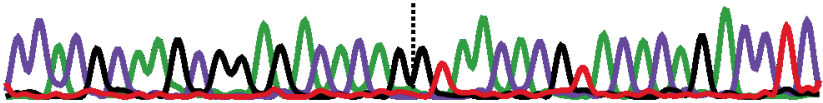

NR2C2 exon 1 : CFAP410 exon 4

G C T T T G G G C C AAA T C C TGA G TT CAACAGCAT CT C CAC C C T

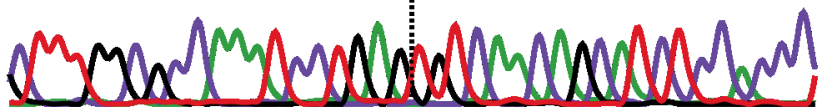

CLASP2 exon $34 \quad$ IL17RD exon 2

AAAAAGATGATGGCGATTCAGGAGTGGGCCAGCCAGCAG

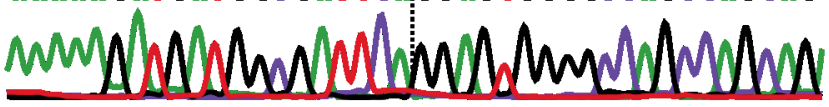

ZNF621 exon 2 LARS2 exon 5

TC CAAACAACT TGGCC TCAGG TCATCAACC C CATGGATG

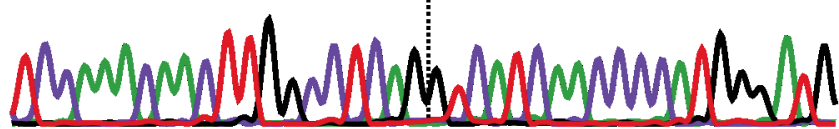

TRAK1 exon $2 \quad T M P 4$ exon 4

AGA A AC T TAAAATACT TC CTCAGGTC CTCAGTGATGGA

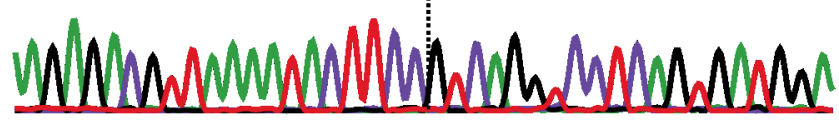

TRAK1 exon $1:$ TIMP4 exon 4

TTATGAA GAATGCT C GGATGGTCAGGT C CT CAGTGATGGA

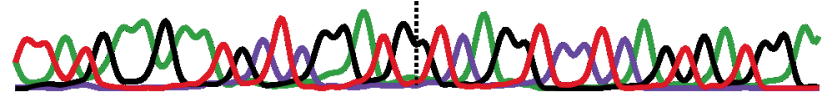

ARHGEF3 exon 3 : CACNA2D2 exon 2

AGGAAATCAAACGTCAGG AGG AT GCAGCACTG GGC C CGGC

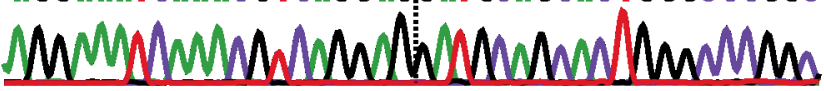

ARHGEF3 exon 2 : CACNA2D2 exon 2

GCT TCAG TCAAACC C TGCAGG ATGCAGCACTG G C C G GC GCTTCAGTCAAACC CTGCAGG gCtocattagct

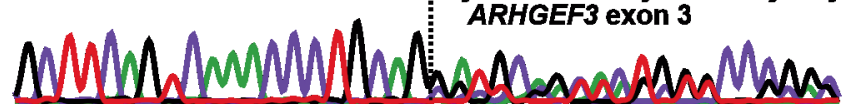

Figure 3. The detected chimeras in the spermatic cord leiomyoma. A: Diagram of the p arm of chromosome 3, showing the mapping positions of the genes contactin 4 (CNTN4); inositol 1;4;5-trisphosphate receptor divergent transcript LITPR1-DT); TIMP metallopeptidase inhibitor 4 (TIMP4); nuclear receptor subfamily 2 group C member 2 (NR2C2); cytoplasmic linker associated protein 2 (CLASP2); zinc finger protein 621 (ZNF621); trafficking kinesin protein 1 (TRAK1); leucyl-tRNA synthetase 2, mitochondrial (LARS2); ras homolog family member A (RHOA); calcium voltage-gated channel auxiliary subunit alpha2delta 2 (CACNA2D2); Rho guanine nucleotide exchange factor 3 (ARHGEF3); and interleukin 17 receptor D (IL17RD); as well as the chimeric genes CNTN4-RHOA, ITPR1DT-NR2C2, TRAK1-TIMP4, CLASP2-IL17RD, ZNF621-LARS2 and ARHGEF3-CACNA2D2. The 个 arrow next to a gene symbol indicates transcription of the gene from centromere to telomere. The $\downarrow$ arrow indicates transcription of the gene from telomere to centromere. B: Partial sequence chromatograms showing the junction positions in the chimeric transcripts CNTN4-RHOA, ITPR1-DT-NR2C2, NR2C2-CFAP410, CLASP2-IL17RD, ZNF621-LARS2, TRAK1-TIMP4 and ARHGEF3-CACNA2D2. 
microtubule growth or shrinkage $(85,86)$. CLASP2 functions in various microtubule-dependent processes including cell division, cytoskeletal remodeling for cell migration, and vesicle transport between intracellular structures and the plasma membrane (87). CLASP2 protein has multiple HEAT repeats, a structural motif composed of two alpha helices linked by a short loop (88), two domains from tumour overexpressed gene that interact with $\alpha \beta$-tubulin, contributing to microtubule dynamics $(89,90)$, a region for interaction of microtubule-associated protein RP/EB family member 1 (MAPRE1, also known as EB1) $(85,91)$, and a carboxyl terminal region which interacts with CLIP1 protein and is required for the localization of CLASP2 protein to the Golgi apparatus and kinetochores (92).

The IL17RD gene codes for a single pass transmembrane protein mainly located in plasma membrane and regulating various signal pathways such as fibroblast growth factor and mitogen-activated protein kinase/extracellular signalregulated kinase signal pathways (93-95). Murine models and expression patterns indicate that $I L 17 R D$ is a tumorsuppressor gene (96-100). Thus, CLASP2-IL17RD chimeric transcript would produce a chimeric protein affecting microtubules and signaling pathways.

In summary, our data, together with those previously published, indicate the existence of a group of leiomyomas cytogenetically characterized by aberration of the $p$ arm of chromosome 3 and the formation of fusion genes. A chromothripsis event seems to lie behind the pathogenetic changes that occurred in this para-testicular leiomyoma, resulting in multiple fusion genes.

\section{Conflicts of Interest}

No potential conflicts of interest exist.

\section{Authors' Contributions}

IP designed and supervised the research, performed molecular genetic and bioinformatic analyses, and wrote the article. LG performed cytogenetic analyses. KA performed molecular genetic analyses and evaluated the data. IL performed the pathological examination. SH assisted with experimental design and writing of the article. All Authors read and approved of the final article.

\section{Acknowledgements}

This work was supported by grants from Radiumhospitalets Legater.

\section{References}

1 Zimmermann A, Bernuit D, Gerlinger C, Schaefers $M$ and Geppert K: Prevalence, symptoms and management of uterine fibroids: an international internet-based survey of 21,746 women. BMC Womens Health 12: 6, 2012. PMID: 22448610. DOI: $10.1186 / 1472-6874-12-6$
2 Giuliani E, As-Sanie S and Marsh EE: Epidemiology and management of uterine fibroids. Int J Gynaecol Obstet 149(1): 3-9, 2020. PMID: 31960950. DOI: 10.1002/ijgo.13102

3 Billings SD, Folpe AL and Weiss SW: Do leiomyomas of deep soft tissue exist? An analysis of highly differentiated smooth muscle tumors of deep soft tissue supporting two distinct subtypes. Am J Surg Pathol 25(9): 1134-1142, 2001. PMID: 11688572. DOI: 10.1097/00000478-200109000-00003

4 Fasih N, Prasad Shanbhogue AK, Macdonald DB, Fraser-Hill MA, Papadatos D, Kielar AZ, Doherty GP, Walsh C, McInnes $\mathrm{M}$ and Atri $\mathrm{M}$ : Leiomyomas beyond the uterus: unusual locations, rare manifestations. Radiographics 28(7): 1931-1948, 2008. PMID: 19001649. DOI: 10.1148/rg.287085095

5 Miettinen M: Smooth muscle tumors of soft tissue and nonuterine viscera: biology and prognosis. Mod Pathol 27(Suppl 1): S17-S29, 2014. PMID: 24384850. DOI: 10.1038/modpathol. 2013.178

6 Commandeur AE, Styer AK and Teixeira JM: Epidemiological and genetic clues for molecular mechanisms involved in uterine leiomyoma development and growth. Hum Reprod Update 21(5): 593-615, 2015. PMID: 26141720. DOI: 10.1093/humupd/ $\mathrm{dmv} 030$

7 Laganà AS, Vergara D, Favilli A, La Rosa VL, Tinelli A, Gerli S, Noventa M, Vitagliano A, Triolo O, Rapisarda AMC and Vitale SG: Epigenetic and genetic landscape of uterine leiomyomas: a current view over a common gynecological disease. Arch Gynecol Obstet 296(5): 855-867, 2017. PMID: 28875276. DOI: $10.1007 / \mathrm{s} 00404-017-4515-5$

8 McWilliams MM and Chennathukuzhi VM: Recent advances in uterine fibroid etiology. Semin Reprod Med 35(2): 181-189, 2017. PMID: 28278535. DOI: 10.1055/s-0037-1599090

9 Baranov VS, Osinovskaya NS and Yarmolinskaya MI: Pathogenomics of uterine fibroids development. Int J Mol Sci 20(24): 6151, 2019. PMID: 31817606. DOI: 10.3390/ijms20246151

10 Nibert $\mathrm{M}$ and Heim S: Uterine leiomyoma cytogenetics. Genes Chromosomes Cancer 2(1): 3-13, 1990. PMID: 2278965. DOI: $10.1002 / \mathrm{gcc} .2870020103$

11 Ligon AH and Morton CC: Leiomyomata: heritability and cytogenetic studies. Hum Reprod Update 7(1): 8-14, 2001. PMID: 11212080. DOI: 10.1093/humupd/7.1.8

12 Mäkinen N, Heinonen HR, Moore S, Tomlinson IP, van der Spuy ZM and Aaltonen LA: MED12 exon 2 mutations are common in uterine leiomyomas from South African patients. Oncotarget 2(12): 966-969, 2011. PMID: 22182697. DOI: 10.18632/oncotarget.370

13 Mäkinen N, Mehine M, Tolvanen J, Kaasinen E, Li Y, Lehtonen HJ, Gentile M, Yan J, Enge M, Taipale M, Aavikko M, Katainen R, Virolainen E, Böhling T, Koski TA, Launonen V, Sjöberg J, Taipale J, Vahteristo P and Aaltonen LA: MED12, the mediator complex subunit 12 gene, is mutated at high frequency in uterine leiomyomas. Science 334(6053): 252-255, 2011. PMID: 21868628. DOI: $10.1126 /$ science. 1208930

14 Heinonen HR, Sarvilinna NS, Sjöberg J, Kämpjärvi K, Pitkänen E, Vahteristo P, Mäkinen N and Aaltonen LA: MED12 mutation frequency in unselected sporadic uterine leiomyomas. Fertil Steril 102(4): 1137-1142, 2014. PMID: 25108465. DOI: 10.1016/j.fertnstert.2014.06.040

15 Mehine M, Kaasinen E, Heinonen HR, Mäkinen N, Kämpjärvi K, Sarvilinna N, Aavikko M, Vähärautio A, Pasanen A, Bützow R, Heikinheimo O, Sjöberg J, Pitkänen E, Vahteristo P and Aaltonen LA: Integrated data analysis reveals uterine leiomyoma 
subtypes with distinct driver pathways and biomarkers. Proc Natl Acad Sci USA 113(5): 1315-1320, 2016. PMID: 26787895. DOI: $10.1073 /$ pnas.1518752113

16 Teyssier JR and Ferre D: Frequent clonal chromosomal changes in human non-malignant tumors. Int J Cancer 44(5): 828-832, 1989. PMID: 2583864. DOI: 10.1002/ijc.2910440514

17 Bardi G, Johansson B, Pandis N, Heim S, Mandahl N, BakJensen E, Frederiksen H, Andrén-Sandberg A and Mitelman F: Recurrent chromosome aberrations in abdominal smooth muscle tumors. Cancer Genet Cytogenet 62(1): 43-46, 1992. PMID: 1521232. DOI: 10.1016/0165-4608(92)90036-8

18 Dal Cin P, Aly MS, Dewever I, Vandamme B and Vandenberghe $\mathrm{H}$ : Does chromosome investigation discriminate between benign and malignant gastrointestinal leiomyomatous tumors? Diag Oncol 2(1): 55-59, 1992.

19 Heidet L, Boye E, Cai Y, Sado Y, Zhang X, Fléjou JF, Fékété F, Ninomiya Y, Gubler MC and Antignac C: Somatic deletion of the 5 ' ends of both the COL4A5 and COL4A6 genes in a sporadic leiomyoma of the esophagus. Am J Pathol 152(3): $673-$ 678, 1998. PMID: 9502408.

20 Panagopoulos I, Gorunova L, Lund-Iversen M, Lobmaier I, Bjerkehagen B and Heim S: Recurrent fusion of the genes FN1 and ALK in gastrointestinal leiomyomas. Mod Pathol 29(11): 1415-1423, 2016. PMID: 27469327. DOI: 10.1038/ modpathol.2016.129

21 Panagopoulos I, Gorunova L, Bjerkehagen B and Heim S: Fusion of the genes EWSR 1 and PBX3 in retroperitoneal leiomyoma with $\mathrm{t}(9 ; 22)(\mathrm{q} 33 ; \mathrm{q} 12)$. PLoS One 10(4): e0124288, 2015. PMID: 25875009. DOI: 10.1371/journal. pone. 0124288

22 Panagopoulos I, Gorunova L, Bjerkehagen B and Heim S: Novel KAT6B-KANSL1 fusion gene identified by RNA sequencing in retroperitoneal leiomyoma with $\mathrm{t}(10 ; 17)(\mathrm{q} 22 ; \mathrm{q} 21)$. PLoS One 10(1): e0117010, 2015. PMID: 25621995. DOI: 10.1371/ journal.pone. 0117010

23 Panagopoulos I, Gorunova L, Brunetti M, Agostini A, Andersen HK, Lobmaier I, Bjerkehagen B and Heim S: Genetic heterogeneity in leiomyomas of deep soft tissue. Oncotarget 8(30): 48769-48781, 2017. PMID: 28591699. DOI: 10.18632/ oncotarget.17953

24 Gorunova L, Bjerkehagen B and Heim S: Paratesticular leiomyoma with a der(14)t(12;14)(q15;q24). Cancer Genet 204(8): 465-468, 2011. PMID: 21962898. DOI: 10.1016/ j.cancergen.2011.06.005

25 Panagopoulos I, Gorunova L, Lund-Iversen M, Andersen K, Andersen HK, Lobmaier I, Bjerkehagen B and Heim S: Cytogenetics of spindle cell/pleomorphic lipomas: Karyotyping and FISH analysis of 31 tumors. Cancer Genomics Proteomics 15(3): 193-200, 2018. PMID: 29695401. DOI: $10.21873 / \mathrm{cgp}$. 20077

26 Panagopoulos I, Gorunova L, Andersen K, Lund-Iversen M, Lobmaier I, Micci F and Heim S: NDRG1-PLAG1 and TRPS1PLAG1 fusion genes in chondroid syringoma. Cancer Genomics Proteomics 17(3): 237-248, 2020. PMID: 32345665. DOI: $10.21873 / \operatorname{cgp} .20184$

27 Kangaspeska S, Hultsch S, Edgren H, Nicorici D, Murumägi A and Kallioniemi O: Reanalysis of RNA-sequencing data reveals several additional fusion genes with multiple isoforms. PLoS One 7(10): e48745, 2012. PMID: 23119097. DOI: 10.1371/ journal.pone. 0048745
28 Nicorici D, Satalan M, Edgren H, Kangaspeska S, Murumagi A, Kallioniemi O, Virtanen S and Kilkku O: FusionCatcher - a tool for finding somatic fusion genes in paired-end RNA-sequencing data. bioRxiv, 2014. DOI: 10.1101/011650

29 Altschul SF, Gish W, Miller W, Myers EW and Lipman DJ: Basic local alignment search tool. J Mol Biol 215(3): 403-410, 1990. PMID: 2231712. DOI: 10.1016/S0022-2836(05)80360-2

30 Mitelman F, Johansson B and Mertens F: Mitelman Database of Chromosome Aberrations and Gene Fusions in Cancer, 2021. Available at: https://mitelmandatabase.isb-cgc.org/[Last accessed on April 25, 2021]

$31 \mathrm{Hu}$ J and Surti U: Subgroups of uterine leiomyomas based on cytogenetic analysis. Hum Pathol 22(10): 1009-1016, 1991. PMID: 1842373. DOI: 10.1016/0046-8177(91)90009-e

32 Nilbert M, Heim S, Mandahl N, Flodérus UM, Willén H and Mitelman F: Characteristic chromosome abnormalities, including rearrangements of $6 p, \operatorname{del}(7 q),+12$, and $t(12 ; 14)$, in 44 uterine leiomyomas. Hum Genet 85(6): 605-611, 1990. PMID: 2227952. DOI: $10.1007 / \mathrm{BF} 00193583$

33 Nilbert M, Heim S, Mandahl N, Flodérus UM, Willén H and Mitelman F: Trisomy 12 in uterine leiomyomas. A new cytogenetic subgroup. Cancer Genet Cytogenet 45(1): 63-66, 1990. PMID: 2302686. DOI: 10.1016/0165-4608(90)90067-k

34 Christacos NC, Quade BJ, Dal Cin P and Morton CC: Uterine leiomyomata with deletions of Ip represent a distinct cytogenetic subgroup associated with unusual histologic features. Genes Chromosomes Cancer 45(3): 304-312, 2006. PMID: 16320247. DOI: $10.1002 /$ gcc. 20291

35 Meloni AM, Surti U, Contento AM, Davare J and Sandberg AA: Uterine leiomyomas: cytogenetic and histologic profile. Obstet Gynecol 80(2): 209-217, 1992. PMID: 1635734.

36 Horton ES, Dobin SM and Donner LR: Leiomyoma of the urinary bladder: a cytogenetic study of a case. Cancer Genet Cytogenet 177(2): 147-148, 2007. PMID: 17854672. DOI: 10.1016/j.cancergencyto.2007.06.009

37 Klemke M, Meyer A, Nezhad MH, Bartnitzke S, Drieschner N, Frantzen C, Schmidt EH, Belge G and Bullerdiek J: Overexpression of HMGA2 in uterine leiomyomas points to its general role for the pathogenesis of the disease. Genes Chromosomes Cancer 48(2): 171-178, 2009. PMID: 18980243. DOI: 10.1002/gcc.20627

38 Nezhad MH, Drieschner N, Helms S, Meyer A, Tadayyon M, Klemke M, Belge G, Bartnitzke S, Burchardt K, Frantzen C, Schmidt EH and Bullerdiek J: 6p21 rearrangements in uterine leiomyomas targeting HMGA1. Cancer Genet Cytogenet 203(2): 247-252, 2010. PMID: 21156240. DOI: 10.1016/j.cancergencyto. 2010.08.005

39 Karaiskos C, Pandis N, Bardi G, Sfikas K, Tserkezoglou A, Fotiou S and Heim S: Cytogenetic findings in uterine epithelioid leiomyomas. Cancer Genet Cytogenet 80(2): 103-106, 1995. PMID: 7736423. DOI: 10.1016/0165-4608(94)00167-a

40 Nilbert M, Heim S, Mandahl N, Flodérus UM, Willén H and Mitelman F: Karyotypic rearrangements in 20 uterine leiomyomas. Cytogenet Cell Genet 49(4): 300-304, 1988. PMID: 3248388. DOI: $10.1159 / 000132682$

41 Stern C, Deichert U, Thode B, Bartnitzke S and Bullerdiek J: Cytogenetic subtyping of 139 uterine leiomyoma. Geburtshilfe Frauenheilkd 52(12): 767-772, 1992. PMID: 1490556. DOI: 10.1055/s-2007-1023809

42 Vanni R, Lecca $U$ and Faa G: Uterine leiomyoma cytogenetics. II. Report of forty cases. Cancer Genet 
Cytogenet 53(2): 247-256, 1991. PMID: 2065298. DOI: 10.1016/0165-4608(91)90101-y

43 Mark J, Havel G, Dahlenfors R and Wedell B: Cytogenetics of multiple uterine leiomyomas, parametrial leiomyoma and disseminated peritoneal leiomyomatosis. Anticancer Res 11(1): 33-39, 1991. PMID: 2018368.

44 Mark J, Havel G, Grepp C, Dahlenfors R and Wedell B: Chromosomal patterns in human benign uterine leiomyomas. Cancer Genet Cytogenet 44(1): 1-13, 1990. PMID: 2293875. DOI: 10.1016/0165-4608(90)90192-d

45 Pandis N, Heim S, Bardi G, Flodérus UM, Willén H, Mandahl $\mathrm{N}$ and Mitelman F: Chromosome analysis of 96 uterine leiomyomas. Cancer Genet Cytogenet 55(1): 11-18, 1991. PMID: 1913597. DOI: 10.1016/0165-4608(91)90229-n

46 Rein MS, Powell WL, Walters FC, Weremowicz S, Cantor RM, Barbieri RL and Morton CC: Cytogenetic abnormalities in uterine myomas are associated with myoma size. Mol Hum Reprod 4(1): 83-86, 1998. PMID: 9510016. DOI: 10.1093/ molehr/4.1.83

47 Korbel JO and Campbell PJ: Criteria for inference of chromothripsis in cancer genomes. Cell 152(6): 1226-1236, 2013. PMID: 23498933. DOI: 10.1016/j.cell.2013.02.023

48 Koltsova AS, Pendina AA, Efimova OA, Chiryaeva OG, Kuznetzova TV and Baranov VS: On the complexity of mechanisms and consequences of chromothripsis: an update. Front Genet 10: 393, 2019. PMID: 31114609. DOI: 10.3389/ fgene.2019.00393

49 Mehine M, Kaasinen E, Mäkinen N, Katainen R, Kämpjärvi K, Pitkänen E, Heinonen HR, Bützow R, Kilpivaara O, Kuosmanen A, Ristolainen H, Gentile M, Sjöberg J, Vahteristo P and Aaltonen LA: Characterization of uterine leiomyomas by wholegenome sequencing. N Engl J Med 369(1): 43-53, 2013. PMID: 23738515. DOI: $10.1056 /$ NEJMoa1302736

50 Holzmann C, Markowski DN, Koczan D, Küpker W, Helmke $\mathrm{BM}$ and Bullerdiek J: Cytogenetically normal uterine leiomyomas without MED12-mutations - a source to identify unknown mechanisms of the development of uterine smooth muscle tumors. Mol Cytogenet 7(1): 88, 2014. PMID: 25506394. DOI: 10.1186/s13039-014-0088-1

51 Mehine M, Mäkinen N, Heinonen HR, Aaltonen LA and Vahteristo P: Genomics of uterine leiomyomas: insights from high-throughput sequencing. Fertil Steril 102(3): 621-629, 2014. PMID: 25106763. DOI: 10.1016/j.fertnstert.2014.06.050

52 Pendina AA, Koltsova AS, Efimova OA, Malysheva OV, Osinovskaya NS, Sultanov IY, Tikhonov AV, Shved NY, Chiryaeva OG, Simareva AD, Kakhiani MI and Baranov VS: Case of chromothripsis in a large solitary non-recurrent uterine leiomyoma. Eur J Obstet Gynecol Reprod Biol 219: 134-136, 2017. PMID: 29103617. DOI: 10.1016/j.ejogrb.2017.10.028

53 Hansford LM, Smith SA, Haber M, Norris MD, Cheung B and Marshall GM: Cloning and characterization of the human neural cell adhesion molecule, CNTN4 (alias BIG-2). Cytogenet Genome Res 101(1): 17-23, 2003. PMID: 14571131. DOI: $10.1159 / 000073412$

54 Deng Z, Jia Y, Liu H, He M, Yang Y, Xiao W and Li Y: RhoA/ROCK pathway: implication in osteoarthritis and therapeutic targets. Am J Transl Res 11(9): 5324-5331, 2019. PMID: 31632513.

55 Ueyama T: Rho-family small GTPases: From highly polarized sensory neurons to cancer cells. Cells 8(2): 92, 2019. PMID: 30696065. DOI: $10.3390 /$ cells 8020092
56 Kloc M, Uosef A, Kubiak JZ and Ghobrial RM: Role of macrophages and RhoA pathway in atherosclerosis. Int J Mol Sci 22(1): 216, 2020. PMID: 33379334. DOI: 10.3390/ijms22010216

57 Seccia TM, Rigato M, Ravarotto V and Calò LA: ROCK (RhoA/Rho Kinase) in cardiovascular-renal pathophysiology: A review of new advancements. J Clin Med 9(5): 1328, 2020. PMID: 32370294. DOI: $10.3390 / \mathrm{jcm} 9051328$

58 Zhang Y, Saradna A, Ratan R, Ke X, Tu W, Do DC, Hu C and Gao P: RhoA/Rho-kinases in asthma: from pathogenesis to therapeutic targets. Clin Transl Immunology 9(5): e01134, 2020. PMID: 32355562. DOI: 10.1002/cti2.1134

59 Aspenström P: Activated Rho GTPases in cancer-The beginning of a new paradigm. Int J Mol Sci 19(12): 3949, 2018. PMID: 30544828. DOI: 10.3390/ijms 19123949

60 Jung H, Yoon SR, Lim J, Cho HJ and Lee HG: Dysregulation of Rho GTPases in human cancers. Cancers (Basel) 12(5): 1179, 2020. PMID: 32392742. DOI: 10.3390/cancers 12051179

61 Kirkwood KL, Homick K, Dragon MB and Bradford PG: Cloning and characterization of the type I inositol 1,4,5trisphosphate receptor gene promoter. Regulation by 17 betaestradiol in osteoblasts. J Biol Chem 272(36): 22425-22431, 1997. PMID: 9278393. DOI: $10.1074 /$ jbc.272.36.22425

62 Deelman LE, Jonk LJ and Henning RH: The isolation and characterization of the promoter of the human type 1 inositol 1,4,5-trisphosphate receptor. Gene 207(2): 219-225, 1998. PMID: 9511764. DOI: 10.1016/s0378-1119(97)00630-6

63 Lin SJ, Yang DR, Yang G, Lin CY, Chang HC, Li G and Chang C: TR2 and TR4 orphan nuclear receptors: an overview. Curr Top Dev Biol 125: 357-373, 2017. PMID: 28527578. DOI: 10.1016/bs.ctdb.2017.02.002

64 Fang X, Lin H, Wang X, Zuo Q, Qin J and Zhang P: The NEK1 interactor, C21ORF2, is required for efficient DNA damage repair. Acta Biochim Biophys Sin (Shanghai) 47(10): 834-841, 2015. PMID: 26290490. DOI: 10.1093/abbs/gmv076

65 Thiesen S, Kübart S, Ropers HH and Nothwang HG: Isolation of two novel human RhoGEFs, ARHGEF3 and ARHGEF4, in 3p13-21 and 2q22. Biochem Biophys Res Commun 273(1): 364369, 2000. PMID: 10873612. DOI: 10.1006/bbrc.2000.2925

66 Arthur WT, Ellerbroek SM, Der CJ, Burridge K and Wennerberg $\mathrm{K}$ : XPLN, a guanine nucleotide exchange factor for RhoA and RhoB, but not RhoC. J Biol Chem 277(45): 42964-42972, 2002. PMID: 12221096. DOI: 10.1074/jbc.M207401200

67 Khanna N, Fang Y, Yoon MS and Chen J: XPLN is an endogenous inhibitor of mTORC2. Proc Natl Acad Sci USA 110(40): 15979-15984, 2013. PMID: 24043828. DOI: $10.1073 /$ pnas. 1310434110

68 Bonnefond L, Fender A, Rudinger-Thirion J, Giegé R, Florentz $\mathrm{C}$ and Sissler M: Toward the full set of human mitochondrial aminoacyl-tRNA synthetases: characterization of AspRS and TyrRS. Biochemistry 44(12): 4805-4816, 2005. PMID: 15779907. DOI: $10.1021 / \mathrm{bi0} 07527 \mathrm{z}$

69 Stowers RS, Megeath LJ, Górska-Andrzejak J, Meinertzhagen IA and Schwarz TL: Axonal transport of mitochondria to synapses depends on milton, a novel Drosophila protein. Neuron 36(6): 1063-1077, 2002. PMID: 12495622. DOI: 10.1016/s08966273(02)01094-2

70 Webber E, Li L and Chin LS: Hypertonia-associated protein Trak1 is a novel regulator of endosome-to-lysosome trafficking. J Mol Biol 382(3): 638-651, 2008. PMID: 18675823. DOI: 10.1016/j.jmb.2008.07.045 
71 Brickley K, Pozo K and Stephenson FA: N-acetylglucosamine transferase is an integral component of a kinesin-directed mitochondrial trafficking complex. Biochim Biophys Acta 1813(1): 269-281, 2011. PMID: 21034780. DOI: 10.1016/ j.bbamcr.2010.10.011

72 Brickley K and Stephenson FA: Trafficking kinesin protein (TRAK)-mediated transport of mitochondria in axons of hippocampal neurons. J Biol Chem 286(20): 18079-18092, 2011. PMID: 21454691. DOI: 10.1074/jbc.M111.236018

73 van Spronsen M, Mikhaylova M, Lipka J, Schlager MA, van den Heuvel DJ, Kuijpers M, Wulf PS, Keijzer N, Demmers J, Kapitein LC, Jaarsma D, Gerritsen HC, Akhmanova A and Hoogenraad CC: TRAK/Milton motor-adaptor proteins steer mitochondrial trafficking to axons and dendrites. Neuron 77(3): 485-502, 2013. PMID: 23395375. DOI: 10.1016/j.neuron.2012.11.027

74 Barel O, Malicdan MCV, Ben-Zeev B, Kandel J, Pri-Chen H, Stephen J, Castro IG, Metz J, Atawa O, Moshkovitz S, Ganelin E, Barshack I, Polak-Charcon S, Nass D, Marek-Yagel D, Amariglio N, Shalva N, Vilboux T, Ferreira C, Pode-Shakked B, Heimer G, Hoffmann C, Yardeni T, Nissenkorn A, Avivi C, Eyal E, Kol N, Glick Saar E, Wallace DC, Gahl WA, Rechavi G, Schrader M, Eckmann DM and Anikster Y: Deleterious variants in TRAK1 disrupt mitochondrial movement and cause fatal encephalopathy. Brain 140(3): 568-581, 2017. PMID: 28364549. DOI: $10.1093 /$ brain/awx002

75 Iyer SP, Akimoto Y and Hart GW: Identification and cloning of a novel family of coiled-coil domain proteins that interact with O-GlcNAc transferase. J Biol Chem 278(7): 5399-5409, 2003. PMID: 12435728. DOI: 10.1074/jbc.M209384200

76 Pekkurnaz G, Trinidad JC, Wang X, Kong D and Schwarz TL: Glucose regulates mitochondrial motility via Milton modification by O-GlcNAc transferase. Cell 158(1): 54-68, 2014. PMID: 24995978. DOI: 10.1016/j.cell.2014.06.007

77 Greene J, Wang M, Liu YE, Raymond LA, Rosen C and Shi YE: Molecular cloning and characterization of human tissue inhibitor of metalloproteinase 4. J Biol Chem 271(48): 30375-30380, 1996. PMID: 8939999. DOI: 10.1074/jbc.271.48.30375

78 Liu YE, Wang M, Greene J, Su J, Ullrich S, Li H, Sheng S, Alexander P, Sang QA and Shi YE: Preparation and characterization of recombinant tissue inhibitor of metalloproteinase 4 (TIMP-4). J Biol Chem 272(33): 2047920483, 1997. PMID: 9252358. DOI: 10.1074/jbc.272.33.20479

79 Stratmann B, Farr M and Tschesche H: MMP-TIMP interaction depends on residue 2 in TIMP-4. FEBS Lett 507(3): 285-287, 2001. PMID: 11696356. DOI: 10.1016/s0014-5793(01)02987-8

80 Stratmann B, Farr M and Tschesche H: Characterization of Cterminally truncated human tissue inhibitor of metalloproteinases-4 expressed in Pichia pastoris. Biol Chem 382(6): 987-991, 2001. PMID: 11501766. DOI: 10.1515/ BC.2001.124

81 Galjart N: Plus-end-tracking proteins and their interactions at microtubule ends. Curr Biol 20(12): R528-R537, 2010. PMID: 20620909. DOI: 10.1016/j.cub.2010.05.022

82 Ferreira JG, Pereira AL and Maiato H: Microtubule plus-end tracking proteins and their roles in cell division. Int Rev Cell Mol Biol 309: 59-140, 2014. PMID: 24529722. DOI: 10.1016/B978-0-12-800255-1.00002-8

83 Langlais P, Dillon JL, Mengos A, Baluch DP, Ardebili R, Miranda DN, Xie X, Heckmann BL, Liu J and Mandarino LJ: Identification of a role for CLASP2 in insulin action. J Biol
Chem 287(46): 39245-39253, 2012. PMID: 22992739. DOI: 10.1074/jbc.M112.394148

84 Gardner MK, Zanic M and Howard J: Microtubule catastrophe and rescue. Curr Opin Cell Biol 25(1): 14-22, 2013. PMID: 23092753. DOI: 10.1016/j.ceb.2012.09.006

85 Lawrence EJ, Arpag G, Norris SR and Zanic M: Human CLASP2 specifically regulates microtubule catastrophe and rescue. Mol Biol Cell 29(10): 1168-1177, 2018. PMID: 29540526. DOI: $10.1091 / \mathrm{mbc} . E 18-01-0016$

86 Lawrence EJ and Zanic M: Rescuing microtubules from the brink of catastrophe: CLASPs lead the way. Curr Opin Cell Biol 56: 94101, 2019. PMID: 30453184. DOI: 10.1016/j.ceb.2018.10.011

87 Lawrence EJ, Zanic M and Rice LM: CLASPs at a glance. J Cell Sci 133(8): jes243097, 2020. PMID: 32332092. DOI: $10.1242 /$ jcs. 243097

88 Yoshimura SH and Hirano T: HEAT repeats - versatile arrays of amphiphilic helices working in crowded environments? J Cell Sci 129(21): 3963-3970, 2016. PMID: 27802131. DOI: $10.1242 /$ jcs. 185710

89 Slep KC: The role of TOG domains in microtubule plus end dynamics. Biochem Soc Trans 37(Pt 5): 1002-1006, 2009. PMID: 19754440. DOI: 10.1042/BST0371002

90 Maki T, Grimaldi AD, Fuchigami S, Kaverina I and Hayashi I: CLASP2 has two distinct TOG domains that contribute differently to microtubule dynamics. J Mol Biol 427(14): 23792395, 2015. PMID: 26003921. DOI: 10.1016/j.jmb.2015.05.012

91 Mimori-Kiyosue Y, Grigoriev I, Lansbergen G, Sasaki H, Matsui C, Severin F, Galjart N, Grosveld F, Vorobjev I, Tsukita S and Akhmanova A: CLASP1 and CLASP2 bind to EB1 and regulate microtubule plus-end dynamics at the cell cortex. J Cell Biol 168(1): 141-153, 2005. PMID: 15631994. DOI: 10.1083/ jcb.200405094

92 Girão H, Okada N, Rodrigues TA, Silva AO, Figueiredo AC, Garcia Z, Moutinho-Santos T, Hayashi I, Azevedo JE, MacedoRibeiro S and Maiato H: CLASP2 binding to curved microtubule tips promotes flux and stabilizes kinetochore attachments. J Cell Biol 219(2): e201905080, 2020. PMID: 31757788. DOI: 10.1083/jcb.201905080

93 Rong Z, Wang A, Li Z, Ren Y, Cheng L, Li Y, Wang Y, Ren F, Zhang X, Hu J and Chang Z: IL-17RD (Sef or IL-17RLM) interacts with IL-17 receptor and mediates IL-17 signaling. Cell Res 19(2): 208-215, 2009. PMID: 19079364. DOI: 10.1038/ cr.2008.320

94 Mellett M, Atzei P, Bergin R, Horgan A, Floss T, Wurst W, Callanan JJ and Moynagh PN: Orphan receptor IL-17RD regulates Toll-like receptor signalling via SEFIR/TIR interactions. Nat Commun 6: 6669, 2015. PMID: 25808990. DOI: $10.1038 /$ ncomms 7669

95 Pande S, Yang X and Friesel R: Interleukin-17 receptor D (Sef) is a multi-functional regulator of cell signaling. Cell Commun Signal 19(1): 6, 2021. PMID: 33436016. DOI: 10.1186/s12964020-00695-7

96 Darby S, Sahadevan K, Khan MM, Robson CN, Leung HY and Gnanapragasam VJ: Loss of Sef (similar expression to FGF) expression is associated with high grade and metastatic prostate cancer. Oncogene 25(29): 4122-4127, 2006. PMID: 16474841. DOI: $10.1038 /$ sj.onc. 1209428

97 Zisman-Rozen S, Fink D, Ben-Izhak O, Fuchs Y, Brodski A, Kraus MH, Bejar J and Ron D: Downregulation of Sef, an inhibitor of receptor tyrosine kinase signaling, is common to a 
variety of human carcinomas. Oncogene 26(41): 6093-6098, 2007. PMID: 17420726. DOI: 10.1038/sj.onc.1210424

98 Hori S, Wadhwa K, Pisupati V, Zecchini V, Ramos-Montoya A, Warren AY, Neal DE and Gnanapragasam VJ: Loss of hSef promotes metastasis through upregulation of EMT in prostate cancer. Int J Cancer 140(8): 1881-1887, 2017. PMID: 28073170. DOI: $10.1002 / \mathrm{ijc} .30604$

99 Mishel S, Shneyer B, Korsensky L, Goldshmidt-Tran O, Haber $\mathrm{T}$, Machluf M and Ron D: Delivery of the gene encoding the tumor suppressor Sef into prostate tumors by therapeuticultrasound inhibits both tumor angiogenesis and growth. Sci Rep 7(1): 15060, 2017. PMID: 29118380. DOI: 10.1038/s41598-017$12408-1$
100 Girondel C, Lévesque K, Langlois MJ, Pasquin S, Saba-El-Leil MK, Rivard N, Friesel R, Servant MJ, Gauchat JF, Lesage S and Meloche S: Loss of interleukin-17 receptor D promotes chronic inflammation-associated tumorigenesis. Oncogene 40(2): 452-464, 2021. PMID: 33177649. DOI: 10.1038/s41388-020-01540-4

Received April 18, 2021

Revised May 11, 2021

Accepted May 18, 2021 